\title{
Postgenomic Science, Big Data, and Biosocial Education
}

\author{
Ben Williamson (University of Edinburgh)
}

Genetic science has begun to escape the dark biological politics of twentieth-century eugenics. Since the sequencing of the human genome - the entire genetic structure of human DNA - was accomplished by the Human Genome project in 2003, 'postgenomic' science has advanced considerably (Gibbon et al., 2018). It has ushered in biotechnological and biomedical innovations, while catalysing concern about genome editing (Nuffield Council on Bioethics, 2018) and a 'posthuman future' where 'transhumanists' may transcend biological limits through genetic modification (Rose, 2007). Through the intersection of biological discovery and informatics innovation, genetic 'codes' and computer 'codes', genomic science has become 'bio-informatic' (Stevens, 2016a), giving rise to a new 'postgenomic condition' marked by the role of data-intensive science and biotechnologies in understanding and shaping human life (Reardon, 2017).

Genomic science has opened up the genetic factors involved in education as a new frontier of knowledge production and potential policy influence too, as 'big biodata' about the human genome are analysed for associations with learning, intelligence, attainment, and achievement (Gaysina, 2016). Genomic expertise in education also, however, raises concerns about biological determinism and eugenics, reanimating debates about the genetic inheritance of intelligence and ability (Gillborn, 2016). Focusing on a major 'big biodata' study of the genetics of educational attainment, this essay outlines its implications for educational research, drawing on posthumanist and biosocial theories. Posthumanism refers to how human life has been reconceived in light of developments in informatics, cybernetics, cognitive science, neuroscience and genetics. "The posthuman subject is an amalgam, a collection of heterogeneous components, a material-informational entity whose boundaries undergo continuous construction and reconstruction" (Hayles (1999, p. 3). Contemporary genomics exemplifies how posthuman subjects are conceived in biological and informational terms simultaneously. Biosocial theorists also pay special attention to growing recognition in genomics that environmental stimuli, experience, and material surroundings shape the 'plasticity' of 'postgenomic bodies' (Meloni 2018). The materiality of biological life is understood increasingly to be permeable to social influence and power structures as 'the social' gets 'under the skin' to reshape 'the biological' aspects of human life (Meloni, Williams \& Martin, 2016). By drawing on posthumanism and biosocial theory, then, the intention is not to speculate on the genetic engineering of humanmachine hybrids - as in some transhumanist accounts but to acknowledge that learning, intelligence, attainment and so on are increasingly understood as simultaneously biological, technical, cognitive, culturally contingent, and politically and economically shaped (Youdell, 2017). The essay opens up educational genomics to critical study and new analytical opportunities presented by the postgenomic permeability of biological materiality to social shaping and biotechnological influence.

Powerful genomic knowledge

In summer 2018, an international consortium of 80 genetics researchers published a paper establishing a link between genes and educational attainment from a study of over a million people. One of the largest genetics studies ever published in a science journal, it represented a significant step forward for the emerging field of educational genomics. Published in Nature Genetics by the international Social Science Genetic Association Consortium (SSGAC) with consumer genetics company 23andMe, the paper reports findings showing that genetic patterns across a large population are associated with years spent in school (Lee et al., 2018). The scientists identified over a thousand genetic variants linked with educational attainment, particularly those involved in brain-development processes and the formation of neuronal connections in foetuses and newborns. These neuro-biological factors, the scientists claimed, influence psychological development, which in turn affects how long people continue at school.

The SSGAC study is a huge advance in genomics, and a new front of knowledge production in educational research too. As a new field, educational genomics studies genetic differences in learning ability, behaviour, motivation, and achievement (Gaysina, 2016). Importantly, researchers of educational genomics do not assume either that any single genetic factors determine learning ability, cognition or intelligence, or that genes entirely explain their complexity. Practitioners of educational genomics and behavioural genetics look for patterns in huge numbers of genetic factors that might explain behaviours and achievements in individuals, by studying the interaction of genotypes - the full heritable genetic identity of a person - and environmental influences on phenotypical behaviours and traits (such as intelligence).

The SSGAC has positioned itself as a leading consortium for genomic education science. Another key figure is behavioural geneticist Robert Plomin, co-author 
of $G$ is for Genes: The Impact of Genetics on Education and Achievement (Plomin \& Asbury, 2013). Like the SSGAC, Plomin has extensively studied the links between genes and attainment using 'genome-wide association studies' (GWAS) and 'polygenic scoring' (GPS). GWAS methods search the genome for small variations to pinpoint genes that may contribute to particular phenotypical behaviours or traits. A polygenic score is produced by analysing huge number of genetic markers, and their interactions with environmental factors, in order to predict a particular behavioural or psychological trait. Seeking a 'new genetics of intelligence', Plomin and colleagues have used GWAS data to examine genetic factors associated with years spent in education, and polygenic scores to predict academic achievement in schools (Plomin \& von Stumm, 2018). In collaboration with the lead author of the SSGAC study, Plomin and colleagues found substantial increase in heritability that, they argued, "represents a turning point in the social and behavioural sciences because it makes it possible to predict educational achievement for individuals directly from their DNA" (Selzam et al., 2017).

Although educational genomics remains in its infancy, it will advance considerably in coming years, linking genotypes to phenotypical traits, behaviours and other outcomes. Wealthy foundations such as the Wellcome Trust and the Jacobs Foundation are generous sources of educational genomics research awards, building support for evidence-based scientific perspectives on learning. Educational genomics, like other genetic sciences, is being constructed as a novel, innovative field of discovery through funding, infrastructure-building, publications, the formation of international associations, and media attention.

\section{Big biodata science}

Genomics is a big data enterprise involving computers and automated machines in studies of human biology and expanding corporate interests in genetic experimentation (Stevens, 2016). The methodological apparatus of the SSGAC study is huge - dwarfing the technical, methodological, financial and expert resources of other educational research. It is the accomplishment of a wellfunded international team of 80 scientists working across psychology, sociology, behavioural genetics, behavioural science, neurogenomics, economics, biosciences, health sciences, and many others. The team included more than 20 scientists from commercial organisation 23andMe, the Silicon Valley company backed by Google which has actively positioned itself as an alternative to publicly funded forms of biomedical research. The research, then, was distributed across public universities and commercial labs at huge disciplinary and financial scale.

The study is also typical of the big data methods of genetic science. Its biodata sample of over a million people was from two sources. One was the UK Biobank, a huge open access health resource based on a living population of over 500,000 volunteer participants, established by the Medical Research Council and the Wellcome Trust and opened up to scientists in 2012 to provide unprecedented access to large samples of genomic data for analysis. The other biodata was provided by 23andMe itself, the consumer genetics company offering health and ancestry services for profit. The methods of the SSGAC study demonstrate the quantitative and computational complexity of large-scale genetics research. It deployed a range of statistical methods, tests, mathematical formulae, algorithms, data visualisations, software platforms with names such as METAL and PLINK, and bioinformatics platforms called DEPICT, MTAG, PANTHER and MAGMA. As such, the paper is the product of a bioinformatic infrastructure consisting of a huge interdisciplinary science team, generous financial funding, enormous non-profit and private databanks, and highly sophisticated biotechnologies, big data analytics, statistical software, and visualisation.

Further education research will locate itself within such infrastructures of professional expertise, labs, databanks, analytics methods and software. However, as Stevens (2016b, p. 366) notes, the turn to big data in genomic research may actually limit how biological systems are understood, with the notion that the genome is "a meaningful text, a code to be broken, or a dataset with hidden patterns" closing off other conceptions of biology. These developments, then, raise questions about how big data pertaining to educational genomics may be shaped by the analytical practices and biotechnologies used to process them, and the potential consequences of those data being used to inform education policy and practice.

\section{Policy sciences}

The SSGAC research represents potential for education policy to embrace genetics expertise. Though the SSGAC reports no direct policy implications, policymakers seeking explanations for educational attainment could be interested in the results. New kinds of 'bio-edu-policy' authorities are bringing expertise in intervening in human bodies, as well as social bodies such as schools, into education policy (Gulson \& Webb, 2018). If genomic plasticity is characteristic of human biology, then the postgenomic body itself appears amenable to policy intervention. Regalado (2018) notes that one of the SSGAC authors previously stated once polygenic scores could be used to predict IQ, it would trigger a 'serious policy debate' about 'personal eugenics'. Likewise Warner (2018) cautions that conservative economists might translate the SSGAC results into educational policy proposals, asking, "How long before schools subject to performance funding as determined by graduation metrics begin to discriminate against students with low polygenic educational attainment scores?" These concerns point to the possible policy uptake of educational genomics for intelligence selection, ability-grouping and genetic discrimination. 
Genetics in education is already highly politicised. The publication in the mid-1990s of The Bell Curve - a US bestseller proposing genetic explanations for IQ and political uses of intelligence data - rekindled debates about genetic determinism, eugenics, and discrimination (Reardon, 2017). Concerns persist about this 'new geneism' (Gillborn, 2016). Deep polarisation exists between conservative advocates of genetics and left-wing critics, with the former preferring explanations based in biology and the latter seeking environmental explanations (Ball, 2018). A column reporting on the SSGAC study argued "progressives should embrace the genetics of education" as "the power of the genomic revolution [can] be harnessed to create a more equal society", while berating "the long tradition of left-wing thinkers who considered biological research inimical to the goal of social equality" (Harden, 2018). But some outspoken advocates of genetic explanations for education are divisive public figures such as Toby Young (the conservative educational commentator) and Charles Murray (co-author of The Bell Curve). Drawing substantially on The Bell Curve, Young has previously supported 'progressive eugenics', using affordable technologies for 'intelligence maximisation' of children of 'low-IQ' parents, as a way of combating persistent inequality (Brassington, 2018). Speculating that "the left is heading for a reckoning with the new genetics", Young (2018) has attacked liberal progressives' "environmental determinism" as "scientifically indefensible", speculating that left-leaning sociologists will become irrelevant unless they embrace genetics by the mid-2020s. But sociological acceptance of genomics is even a source of concern for Young, since "once left-wing intellectuals finally let go of environmental determinism they may veer too far in the opposite direction and embrace gene editing technologies ... to create the perfect socialist citizen". Given Young's controversial conservative politics, his comments have caused widespread alarm among academics and educators - drawing counterarguments that social interventions rather than 'progressive eugenics' are better solutions to poverty, inequality and 'low IQ' (Feinstein, 2017).

While educational genomics scientists seek to reassure the public their research aims to reduce inequality and achieve greater equity, these reassurances are both obfuscated by ongoing political animosity and deeply questioned as biological explanations for societal problems. Education policy in coming years will have to engage in significant debate about genetics and even personal eugenics, requiring informed participation by social scientists and ethicists whose views on the matter are currently subject to attack from conservative commentators.

\section{An emerging educational bioeconomy}

With growing awareness of genomic science in education, commercial organisations may exploit it to build an educational genetics market of services and products.
Contemporary genomics is already marked by an expanding bioeconomy of products, companies and services, with wealthy labs, biotechnology producers, and consumer genetics startups accumulating lucrative biocapital (Stevens, 2016a). Consumer companies such as 23 andMe have exploited the sequencing of the human genome to launch genetic testing services as commercial products, exemplifying movements in the biomedical field to subject personal data to corporate control (Stevens, 2016b). In the same week the SSGAC study was released, 23andMe also agreed a \$300million deal with big pharmaceutical company GlaxoSmithKline to apply machine learning and artificial intelligence to analyse data from its 5 million customers for medical discovery and pharmaceutical innovation, positioning itself as part of the infrastructure and bioeconomy of genetic pharmaceuticals and education alike.

Other companies may see market potential in educational genomics, such as startup producers of cheap DNA kits for IQ testing in schools, 'intelligence apps', or other genetic ed-tech products (Zimmer, 2018). Major risks would emerge from the expansion of an educational bioeconomy. If genetic predictions become accepted as forecasts of a child's future ability, new approaches may emerge to artificially select future generations (Conley, 2017), thereby anticipating a 'eugenics 2.0 ' for selecting 'smarter' children (Regalado, 2017). While embryo screening and genome editing for 'superabilities' remain illegal in the West (Nuffield Council on Bioethics, 2018), large-scale efforts elsewhere to find the genetic code for high IQ might make selective-intelligence programmes attractive to wealthy parents seeking advantage for their children.

The merging of genetic science, big data and commercial speculation in education could lead to an emerging market in educational genomics biotechnologies and services, where the logics of biocapital accumulation and data analytics combine to push genetic testing and other profiling services in schools. The risk is that obsession with these "slippery genetic predictions could turn people's attention away from other things that influence how children do in school and beyond - things like their family's wealth, the stress in their neighbourhoods, the quality of the schools themselves" (Zimmer, 2017).

\section{Toward critical postgenomic education research}

The expansion of educational genomics raises distinctive challenges for social scientific education research. Within the wider field of sociology and STS research on genomics, researchers are developing novel forms of analysis and critique (Gibbon et al., 2018). Contemporary postgenomic science, with its emphasis on geneenvironment interaction, offers an invitation for social scientists to explore how the biological and the social constitute each other. Biosocial studies, for example, acknowledge that the 'plasticity' of the 
'postgenomic body' is imprinted by social, environmental, and power structures in society (Meloni, 2018).

Biosocial work in education is emerging, with educational researchers seeking to work beyond the historical 'bio/social binary' (Gulson \& Baker, 2018). Developing a 'biosocial education' agenda, Youdell (2017) argues that learning is the result of social and biological entanglements. Biosocial education research takes biological materiality seriously, but also digs critically into how scientists conceptualise the body and make it amenable to experimentation and intervention. A biosocial approach would seek to understand educational genomics in both biological and social scientific terms by appreciating that the social environments in which learning takes place do in fact inscribe themselves on postgenomic bodies. The big biodata of contemporary genomics would have to be understood from a biosocial view as data about social processes and power structures, not only organic biological processes.

Since genetics is a highly data-intensive biotechnological field of experimentation and knowledge production, a biosocial perspective would also address the implications of processing students' genetic data, acknowledging that data are always a partial selection, that their analysis through infrastructures of methods and software packages matters a great deal to the results produced, and that the results can influence subsequent forms of intervention and treatment (Stevens, 2016b). These points raise substantial questions for posthumanist analysis of educational genomics too. To what extent do the algorithms used in educational genomics shape how scientists know and think about education and learning as parts of 'life itself'? Is the 'quantified human' represented by a polygenic score in a DNA database really detailed enough to yield insights to intervene upon embodied students? What kind of posthuman hybrids are produced through the analysis of vast databanks of biodata, and with what consequences? Additionally, biosocial and posthumanist research would be alert to the bioeconomy of commercial companies building biotechnologies for collecting and analysing students' genetic data, and to their influence on the plasticity of students' postgenomic bodies.

\section{Conclusion}

The million-sample SSGAC study is clearly a landmark in genomic education science. Educational genomics is now a field of experimentation and knowledge production requiring novel forms of social scientific and philosophical analysis. A new student subject is emerging from this new field - a posthuman subject and a postgenomic body crafted from experimental biodata, composed through data infrastructure, made possible by biocapital, shaped by ,bio-edu-policy', and potentially open to augmentation, improvement and enhancement through 'eugenics 2.0' biotechnologies. A biosocial and posthumanist approach offers concepts and methods to perform critical postgenomic research as the genetic science of education expands.

\section{References}

Ball, P. (2018). The IQ trap: How the study of genetics could transform education. New Statesman. Retrieved from https://www.newstatesman.com/2018/04/iq-trap-how-study-genetics-could-transform-education on 16.04

Brassington, I. (2018). Toby Young, eugenics, IQ, and the poor. Journal of Medical Ethics blog. Retrieved from https://blogs.bmj.com/medical-ethics/2018/01/08/toby-young-eugenics-iq-and-the-poor-part-1/ on 09.01

Conley, D. (2017). What's your polygenic score? Scientific American. Retrieved from https://blogs.scientificamerican.com/guest-blog/whats-your-polygenic-score/ on 13.03

Feinstein, L. (2017). On genetics and social mobility: why Toby Young's structural inequality argument is not science. LSE British Politics and Policy.Retrieved from http://blogs.lse.ac.uk/politicsandpolicy/on-genetics-and-social-mobility/ on 03.11.

Gaysina, D. (2016). How genetics could help future learners unlock hidden potential. The Conversation. Retrieved from: https://theconversation.com/how-genetics-could-help-future-learners-unlock-hidden-potential-68254 on 15.11

Gibbon, S., Prainsack, B., Hilgartner, S. \& Lamoreaux, J. (eds). (2018). Handbook of genomics, health, and society (2 ${ }^{\text {nd }}$ ed.). Abingdon: Routledge.

Gillborn, D. (2016). Softly, softly: Genetics, intelligence and the hidden racism of the new geneism. Journal of Education Policy, 31(4), 365-388.

Gulson, K. \& Baker, B. (2018). New biological rationalities in education. Discourse: Studies in the cultural politics of education, 39(2), 159-168.

Gulson, K. \& Webb, P.T. (2018). 'Life' and education policy: intervention, augmentation and computation. Discourse: Studies in the cultural politics of education, 39(2), 276-291.

Harden, K.P. (2018, July 24). Why progressives should embrace the genetics of education. The New York Times, Retrieved from https://www.nytimes.com/2018/07/24/opinion/dna-nature-genetics-education.html

Hayles, N.K. (1999). How we became posthuman: Virtual bodies in cybernetics, literature, and informatics. London: University of Chicago Press. 
Lee, J.J., Wedow, R., Okbay, A., et al. (2018). Gene discovery and polygenic prediction from a genome-wide association study of educational attainment in 1.1 million individuals. Nature Genetics, 50, 1112-1121.

Meloni, M. (2018). A postgenomic body: Histories, genealogy, politics. Body \& Society, 24(3), 3-38.

Meloni, M., Williams, S. \& Martin, P. (2016). The biosocial: Sociological themes and issues. Biosocial Matters: Rethinking the Sociology-Biology Relations in the Twenty-First Century. The Sociological Review Monographs, 64(1), 7-25.

Nuffield Council on Bioethics (2018). Genome editing and human reproduction: social and ethical issues. London: Nuffield Council on Bioethics.

Pickersgill, M., Niewohner, J., Muller, R., Martin, P. \& Cunningham-Burley, S. (2013). Mapping the new molecular landscape: social dimensions of epigenetics. New Genetics and Society, 32(4), 429-447.

Plomin, R. \& Asbury, K. (2013). G is for genes: The impact of genetics on education and achievement. Oxford: Wiley Blackwell.

Plomin, R. \& von Stumm, S. (2018). The new genetics of intelligence. Nature Reviews Genetics. doi:10.1038/nrg.2017.104 Reardon, J. (2017). The postgenomic condition: Ethics, justice, and knowledge after the genome. Chicago, IL: University of Chicago Press.

Regalado, A. (2017). Eugenics 2.0: We're at the dawn of choosing embryos by health, height, and more. MIT Technology Review. Retrieved from https://www.technologyreview.com/s/609204/eugenics-20-were-at-the-dawn-of-choosing-embryosby-health-height-and-more/ on 01.11 .

Regalado, A. (2018). DNA tests for IQ are coming, but it might not be smart to take one. MIT Technology Review. Retrieved from https://www.technologyreview.com/s/610339/dna-tests-for-iq-are-coming-but-it-might-not-be-smart-to-take-one/ on 02.04 .

Rose, N. (2007). The politics of life itself: Biomedicine, power, and subjectivity in the twenty-first century. Princeton, NJ: Princeton University Press.

Selzam, S., Krapohl, E., von Stumm, S., O’Reilly, P.F., Rimfield, K., Kovas, Y., Dale, P.S. \& Plomin, R. (2017). Predicting educational achievement from DNA. Molecular Psychiatry, 22, 267-272.

Stevens, H. (2016a). Biotechnology and society. London: University of Chicago Press.

Stevens, H. (2016b). Hadooping the genome: The impact of Big Data tools on biology. BioSocieties ,11(3), 352-371.

Warner, J. (2018). Why we shouldn't embrace the genetics of education. Inside Higher Ed. Retrieved from https://www.insidehighered.com/blogs/just-visiting/why-we-shouldnt-embrace-genetics-education on 26.07.

Youdell, D. (2017). Bioscience and the sociology of education: The case for biosocial education. British Journal of Sociology of Education, 38, 1273-1287.

Young, T. (2018). The left is heading for a reckoning with the new genetics. The Spectator. Retrieved from https://blogs.spectator.co.uk/2018/04/the-left-is-heading-for-a-reckoning-with-the-new-genetics/ on 23.04.

Zimmer, C. (2018). Genetic intelligence tests are next to worthless. The Atlantic. Retrieved from https://www.theatlantic.com/science/archive/2018/05/genetic-intelligence-tests-are-next-to-worthless/561392/ on 29.05.

\section{Recommended Citation}

Williamson, B. (2018). Postgenomic science, Big Data, and biosocial education. On Education. Journal for Research and Debate, 1(2). https://doi.org/10.17899/on_ed.2018.2.7

\section{About the Author}

Ben Williamson is a Chancellor's Fellow at the Edinburgh Futures Institute and Moray House School of Education at the University of Edinburgh. His research focuses on the intersections of digital technology, data, policy and science in education. His book Big Data in Education: The Digital Future of Learning, Policy and Practice was published by Sage in 2017. 